\title{
Factors affecting consumer's bargaining behavior: The case of fashionable clothing
}

\author{
Dinh Tien Minh ${ }^{1}$, Phan Thi Yen Linh ${ }^{1}$, Ho Thi Kieu Nhan ${ }^{1}$, Nguyen Tran Huyen Trang ${ }^{1}$, \\ Tran Le Ngoc Thao Uyen ${ }^{1}$, Do Thi Ngoc Van ${ }^{1}$, Pham Khac Xuan ${ }^{1}$ \\ ${ }^{1}$ University of Economics Ho Chi Minh City, Vietnam \\ *Corresponding author: dinhtienminh@ueh.edu.vn
}

\section{ARTICLE INFO}

DOI: $10.46223 / \mathrm{HCMCOUJS.}$ econ.en.10.1.220.2020

Received: September $10^{\text {th }}, 2019$

Revised: November $25^{\text {th }}, 2019$

Accepted: April 20"th 2020

Keywords:

bargaining behavior, bargaining action, haggling, fashionable clothing, apparel, consumer behavior
Shopping is one of the current trends of the Vietnamese. According to Nielsen's research results about consumer confidence in the fourth quarter of 2017, more than half of Vietnamese people (51\%) use their spare money to buy new clothes at modern business models such as supermarkets, shopping centers, or at very traditional models like street vendors and wet markets where haggling (also known as bargaining) is considered as a common habit for Vietnamese. This is due to business characteristics from a very long time ago in Vietnam. The bargaining behavior is not so hard to recognize in shopping. Even now, a large part of foreign tourists is familiar with the bargaining culture. This study aimed to discover bargaining behavior, the factors affecting such a behavior in buying fashionable clothing of the consumers in Ho Chi Minh City, and to consider whether the differences in bargaining behavior exist among different groups of gender, age, and income.

The research was conducted using mixed methods concluding qualitative research (in-depth interview and focus group) and quantitative one (survey). The results showed that Attitude towards bargaining, Perceived behavioral control, Interest in bargaining affect Consumer's bargaining behavior when buying fashionable clothes. Results were validated in Ho Chi Minh City context, and some conclusions were also presented.

\section{Background and research model}

Bargaining is a process in which buyers and sellers of goods/services argue about the price and the exact nature of the transaction (Putthiwanit \& Santipiriyapon, 2013). This is the behavior that both sellers and buyers are involved in, related to the price of the product or service. If bargaining leads to reaching agreements on terms, the transaction will take place. Bargaining allows sellers to know consumers' willingness to spend, and it also allows buyers to get items at the desired purchase price. Until today, there are so many studies about consumer behavior in general and the specific behaviors such as choice, shopping, intention, buying... The theories that created a steady foundation are the Theory of Rational Action TRA (Ajzen \& Fishbein, 1975) and Theory of Planned Behavior TPB (Ajzen, 1991). According to TRA, the consumer intention is the most important signal predicting consumer behavior. Behavioral intention is influenced by two 
factors, behavior-oriented attitude, and subjective norm. In which, attitude is an expression of that individual's element, expressing positive or negative beliefs to consumption for a product or service and subjective norm also shows the influence of society on individual consumers and their behavior. While $T P B$ is built by adding behavioral control cognitive element to the TRA model. Behavioral control cognitive reflects the ease or difficulty of implementing behaviors. This depends on the availability of resources and opportunities for implementing behavior.

Regarding the bargaining behavior, some previous typical studies can be listed as follow: Lee (2000) reports on retail bargaining behavior of American and Chinese Singaporean customers; Osman-Gani and Tan (2002) study the influence of culture on negotiation styles of Asian mangers; Novemsky and Schweitzer (2004) examine the differential effects of internal and external social comparisons on negotiator satisfaction; Kwon, Schumann, and Fairhurst (2010) study the characteristics of bargain hunters over forward-looking price expectation; and Lichtenstein, Ridgway, and Netemeyer (1993), Freymann (2002), and Putthiwanit (2016). Most of them found that attitude, interest were the most important factors affecting bargaining behavior. For instance, the price is the first factor customers must pay attention to when entering a place to shop (Freymann, 2002). Lichtenstein et al. (1993) point out that customer perceptions of prices may have a positive or negative impact on buying behavior. Customers are willing to pay a high price for a product when they perceive the price with a positive meaning, such as a high price that represents prestige and good quality. On the other hand, consumers who perceive prices in a negative direction often prefer low prices and promotions. In 1973, Kotler demonstrated the external environment that determines the value of goods can also affect customers. Erdem and Darden (1983) found that from the customer point of view, the physical appeal of the shopping place is correlated with the higher decision-making decision compared with the price and the quality of goods.

\section{Suggested Research Model}

The suggested research model that inherits previous theoretical models and studies, and build based on qualitative research includes four factors which are attitude towards bargaining, subjective norms (impact of other people), perceived behavior control (the easy or difficult feelings to bargain), and interest in bargaining affecting the consumer's bargaining behavior when buying fashionable clothing in Ho Chi Minh City. It is also inserted demographic variables such as gender, age, and income to find out the differences in demographic characteristics on the impact.

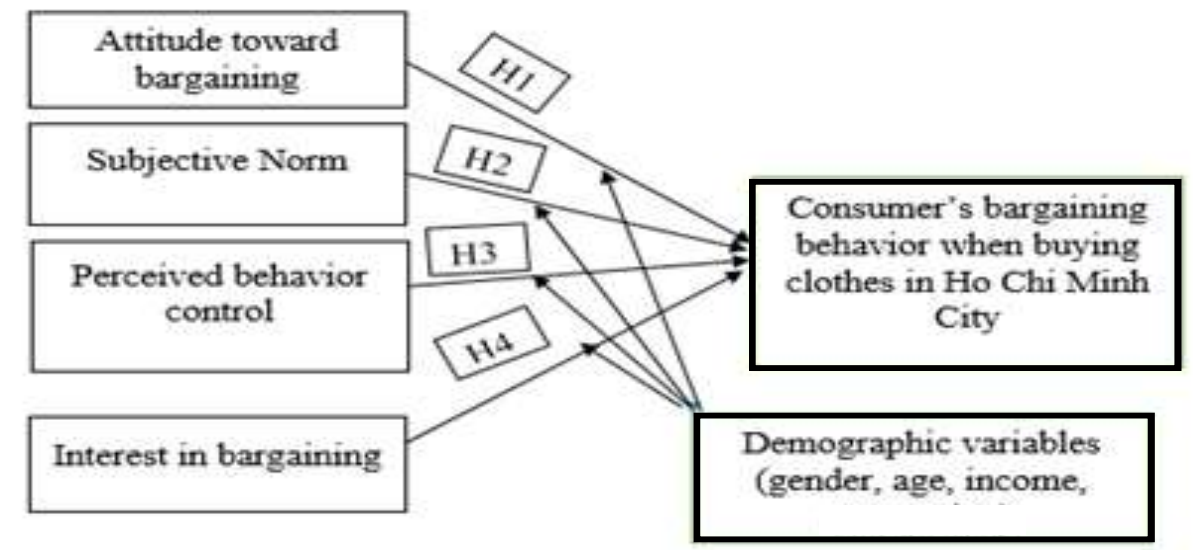

Figure 1. The Research Model

H1: Consumer's attitude toward bargaining has a positive impact on bargaining behavior 
H2: Subjective norm has a positive impact on bargaining behavior

H3: Perceived behavior control has a positive impact on bargaining behavior

H4: The interest in bargaining has a positive impact on bargaining behavior

\section{Methodology}

This study is conducted in two steps: firstly, the qualitative method is carried out in two formats, focus-group discussion of eight people and in-depth interviews with two experts who are experienced traders, market-savvy. The goal is to directly explore ideas to build the model, adjust, and supplement the observed variables of the scales (T. D. Nguyen, 2011). Secondly, research uses the quantitative method throughout face-to-face surveys and online interviews (Google form) for model and hypotheses verification. The questionnaire is designed by Linkert scale five points from one -"Strongly disagree" to five - "Strongly agree".

The collected data is processed by three steps, check for reliability of the scale (Cronbach's alpha), exploratory factor analysis (EFA), and analysis of multiple linear regression (MLR). Besides that, T-test and ANOVA are also used for checking whether the differences in bargaining behavior exist among different groups of gender, age, and income.

\section{Results}

\subsection{Descriptive data}

After eliminating 57 observations, 220 are valid for data processing in which seventy-four received from face-to-face survey $(33.6 \%)$ and one hundred and forty-six received from the online interview (66.4\%).

\section{Table 1}

Statistic of respondents

\begin{tabular}{|c|c|c|c|c|c|c|c|c|c|c|}
\hline \multicolumn{4}{|c|}{ Gender } & \multicolumn{5}{c|}{ Age } & \multicolumn{3}{c|}{ Income } \\
\hline Male & Female & $<23$ y.o & $23-27$ y.o & $28-35$ y.o & $36-45$ y.o & $>45$ y.o & $<5 \mathrm{M}$ đ & $5 \mathrm{M}-10 \mathrm{M}$ đ & $10 \mathrm{M}-15 \mathrm{M}$ đ & $>15 \mathrm{M}$ đ \\
\hline 70 & $\mathbf{1 5 0}$ & $\mathbf{9 4}$ & $\mathbf{4 2}$ & 27 & 29 & 28 & $\mathbf{1 0 7}$ & $\mathbf{7 4}$ & 24 & 15 \\
\hline $31.8 \%$ & $\mathbf{6 8 . 2} \%$ & $\mathbf{4 2 . 7 \%}$ & $\mathbf{1 9 . 1 \%}$ & $12.3 \%$ & $13.2 \%$ & $12.7 \%$ & $\mathbf{4 8 . 6} \%$ & $\mathbf{3 3 . 6 \%}$ & $10.9 \%$ & $6.8 \%$ \\
\hline
\end{tabular}

Source: Research results

Most of the respondents are female, under twenty-three years old (y.o) and monthly income goes around five million (M) VNĐ. The next group falls into the consumers aging from twentythree y.o to twenty-seven y.o and getting from five million VNĐ to ten million VNĐ. This number shows that these segments often goes shopping for clothes in general trade channel (street shops, wet markets) and the consumers, who are older and have higher income, choose modern trade channel (department store, shopping malls) as their priority.

\subsection{Model and hypothesis verification}

At the first step, all scales need to be tested for reliability with Cronbach's Alpha method. The results indicate Attitude towards bargaining (TD thaido) reaching 0.628, Subjective norms (CCQ_chuanchuquan) 0.801, Perceived behavioral control (CN_camnhan) 0.738, Interest in bargaining (TT_thichthu) 0.746 and Consumer's bargaining behavior (HV_hanh_vi) 0.727 . 
Table 2

Reliability by Cronbach's Alpha

\begin{tabular}{|l|c|}
\hline \multicolumn{1}{|c|}{ Factor } & Cronbach's Alpha \\
\hline Attitude towards bargaining (TD_thaido) & 0.628 \\
\hline Subjective norms (CCQ_chuanchuquan) & 0.801 \\
\hline Perceived behavioral control(CN_camnhan) & 0.738 \\
\hline Interest in bargaining (TT_thichthu) & 0.746 \\
\hline Consumer's bargaining behavior(HV_hanh_vi) & 0.727 \\
\hline
\end{tabular}

Source: Research results

Next, EFA analysis gives $\mathrm{KMO}=0.733>0.5$ and Bartlett's $\mathrm{Sig}=0.000<0.05$, Eigenvalue is greater than one, and the total variance extracted $66.326 \%>50 \%$ by Principle component extraction method and Varimax rotation.

Table 3

KMO test

\begin{tabular}{|c|c|c|c|c|c|c|c|c|c|}
\hline \multirow{2}{*}{ Component } & \multicolumn{3}{|c|}{ Initial Eigenvalues } & \multicolumn{3}{c|}{$\begin{array}{c}\text { Extraction Sums of } \\
\text { Squared Loadings }\end{array}$} & \multicolumn{2}{c|}{$\begin{array}{c}\text { Rotation Sums of Squared } \\
\text { Loadings }\end{array}$} \\
\cline { 2 - 10 } & Total & $\begin{array}{c}\text { \% of } \\
\text { Variance }\end{array}$ & $\begin{array}{c}\text { Cumulative } \\
\%\end{array}$ & Total & $\begin{array}{c}\text { \% of } \\
\text { Variance }\end{array}$ & $\begin{array}{c}\text { Cumulative } \\
\%\end{array}$ & Total & $\begin{array}{c}\% \text { of } \\
\text { Variance }\end{array}$ & $\begin{array}{c}\text { Cumulative } \\
\%\end{array}$ \\
\hline 1 & 3,582 & 29,853 & 29,853 & 3,582 & 29,853 & 29,853 & 2,397 & 19,975 & 19,975 \\
\hline 2 & 1,698 & 14,147 & 43,999 & 1,698 & 14,147 & 43,999 & 2,179 & 18,156 & 38,131 \\
\hline 3 & 1,583 & 13,193 & 57,193 & 1,583 & 13,193 & 57,193 & 1,733 & 14,440 & 52,571 \\
\hline 4 & 1,096 & 9,133 & 66,326 & 1,096 & 9,133 & $\mathbf{6 6 , 3 2 6}$ & 1,651 & 13,755 & 66,326 \\
\hline 5 &, 738 & 6,147 & 72,473 & & & & & & \\
\hline
\end{tabular}

Source: Research results

Finally, regression analysis using the enter method was carried out with four independent variables which are Attitude towards bargaining (thaido), Subjective norm (chuanchuquan), Perceived behavioral control (camnhan), Interest in bargaining (thichthu) and one dependent variable Consumer's bargaining behavior (hanh_vi). The results of the regression analysis are presented in Table 4.

\section{Table 4}

First time regression analysis

\begin{tabular}{|c|c|c|c|c|c|c|c|c|}
\hline \multicolumn{9}{|c|}{ Coefficients $^{a}$} \\
\hline & & \multicolumn{2}{|c|}{ Unstandardized Coefficients } & \multirow{2}{*}{$\begin{array}{c}\begin{array}{c}\text { Standardized } \\
\text { Coefficients }\end{array} \\
\text { Beta }\end{array}$} & \multirow[b]{2}{*}{$t$} & \multirow[b]{2}{*}{ Sig. } & \multicolumn{2}{|c|}{ Collinearity Statistics } \\
\hline \multicolumn{2}{|c|}{ Model } & $\mathrm{B}$ & Std. Error & & & & Tolerance & VIF \\
\hline \multirow[t]{5}{*}{1} & (Constant) & 1.833 & .299 & & 6.132 & .000 & & \\
\hline & thaido & .253 & .066 & .240 & 3.852 & .000 & .944 & 1.060 \\
\hline & chuanchuquan & -.035 & .057 & -.042 & -.624 & .533 & .800 & 1.251 \\
\hline & camnhan & .208 & .053 & .263 & 3.901 & .000 & .805 & 1.243 \\
\hline & thichthu & .172 & .064 & .178 & 2.697 & .008 & .840 & 1.190 \\
\hline
\end{tabular}

a. Dependent Variable: hanh_vi

Source: Research results 
Table 5

Second time regression analysis

Model Summary

\begin{tabular}{|l|c|r|r|r|r|}
\hline Model & R & R Square & $\begin{array}{c}\text { Adjusted R } \\
\text { Square }\end{array}$ & $\begin{array}{c}\text { Std. Error of } \\
\text { the Estimate }\end{array}$ & $\begin{array}{c}\text { Durbin- } \\
\text { Watson }\end{array}$ \\
\hline 1 & $.460^{\mathrm{a}}$ & .212 & .201 & .79425 & 1.497 \\
\hline
\end{tabular}

a. Predictors: (Constant), thichthu, thaido, camnhan

b. Dependent Variable: hanh_vi

ANOVA $^{\text {a }}$

\begin{tabular}{|rl|r|r|r|r|r|}
\hline \multicolumn{1}{|c|}{} & \multicolumn{1}{c|}{$\begin{array}{c}\text { Sum of } \\
\text { Squares }\end{array}$} & \multicolumn{1}{c|}{ df } & Mean Square & \multicolumn{1}{c|}{ F } & Sig. \\
\hline 1 & Regression & 36.579 & 3 & 12.193 & 19.328 & $.000^{\mathrm{b}}$ \\
& Residual & 136.261 & 216 & .631 & & \\
& Total & 172.840 & 219 & & & \\
\hline
\end{tabular}

a. Dependent Variable: hanh_vi

b. Predictors: (Constant), thichthu, thaido, camnhan

Coefficients $^{\mathrm{a}}$

\begin{tabular}{|c|c|c|c|c|c|c|c|c|}
\hline \multirow[b]{2}{*}{ Mode } & & \multicolumn{2}{|c|}{ Unstandardized Coefficients } & \multirow{2}{*}{$\begin{array}{c}\begin{array}{c}\text { Standardized } \\
\text { Coefficients }\end{array} \\
\text { Beta }\end{array}$} & \multirow[b]{2}{*}{$t$} & \multirow[b]{2}{*}{ Sig. } & \multicolumn{2}{|c|}{ Collinearity Statistics } \\
\hline & & $B$ & Std. Error & & & & Tolerance & VIF \\
\hline \multirow[t]{4}{*}{1} & (Constant) & 1.796 & .293 & & 6.136 & .000 & & \\
\hline & thaido & .253 & .066 & .240 & 3.865 & .000 & .944 & 1.059 \\
\hline & camnhan & .198 & .051 & .250 & 3.902 & .000 & .888 & 1.126 \\
\hline & thichthu & .161 & .061 & .167 & 2.628 & .009 & .901 & 1.110 \\
\hline
\end{tabular}

a. Dependent Variable: hanh_vi

Source: Research results

Results of the second-time regression analysis in Table 5 give the values Sig. of Attitude towards bargaining (thaido), Perceived behavioral control (camnhan), Interest in bargaining (thichthu) less than 0.05 . Therefore, it can be confirmed that these factors are statistically significant in the model.

Results from ANOVA have coefficient $F=19.328$ with Sig value. $=0.00<0.05$, thus, it can be concluded that the existing independent variables in the model can explain the change of the dependent variable as a whole with a significant of 5\%. This means that the research model is suitable for the data set and can be used.

For the multi-collinearity measurement, the results show that the Variance Inflation Factor $(V I F)$ is from 1.059 to 1.126 meets the satisfaction (VIF <10). So multiple regression model does not have multi-collinearity phenomenon; the relationship between independent variables does not affect the results of the model. 


\subsection{Regression equation}

Multi Linear Regression equation resulting from regression analysis and being based on the standardized coefficient is as follows:

$$
\mathrm{HV}=1.796+0.240 * \mathrm{TD}+0.250 * \mathrm{CN}+0.167 * \mathrm{TT}
$$

As shown in the above formula, the most influential factor on bargaining behavior when buying fashionable clothes is Perceived behavioral control (camnhan) $(\beta=0.250)$, then Attitude towards bargaining (thaido) $(\beta=0.240)$, and then Interest in bargaining (thichthu) $(\beta=0.167)$.

\subsection{Testing the hypothesis}

Hypothesis H1: Consumer's attitude toward bargaining has a positive impact on bargaining behavior. $\mathrm{H} 1$ is accepted thanks to Sig. $=0.00<0.05$ (Table 4). Thus, the more attitude towards bargaining is, the higher level of bargaining behavior happens.

Hypothesis H2: Subjective norm has a positive impact on bargaining behavior. $\mathrm{H} 2$ is rejected due to Sig. $=0.533>0.05$ (Table 4$)$.

Hypothesis H3: Perceived behavior control has a positive impact on bargaining behavior. H3 is accepted thanks to Sig. $=0.00<0.05$ (Table 4). Thus, when consumers feel easier or more difficult to implement bargaining, the higher level of bargaining behavior happens.

Hypothesis H4: The interest in bargaining has a positive impact on bargaining behavior. $\mathrm{H} 4$ is accepted thanks to Sig. $=0.08<0.05$ (Table 4). Thus, the more interest in bargaining is, the higher level of bargaining behavior happens.

Table 6

Results of hypothesis testing

\begin{tabular}{|c|l|c|c|c|}
\hline Hypothesis & \multicolumn{1}{|c|}{ Statement } & Sig. & VIF & Result \\
\hline H1 & $\begin{array}{l}\text { Consumer's attitude towards bargaining has a } \\
\text { positive impact on bargaining behavior }\end{array}$ & 0.00 & 1.060 & Accepted \\
\hline H2 & $\begin{array}{l}\text { Subjective norm has a positive impact on } \\
\text { bargaining behavior }\end{array}$ & \multicolumn{3}{|c|}{ Rejected } \\
\hline H3 & $\begin{array}{l}\text { Perceived behavior control has a positive } \\
\text { impact on bargaining behavior }\end{array}$ & 0.00 & 1.243 & Accepted \\
\hline H4 & $\begin{array}{l}\text { The interest in bargaining has a positive } \\
\text { impact on bargaining behavior }\end{array}$ & 0.08 & 1.190 & Accepted \\
\hline
\end{tabular}

Source: Research results

\subsection{Testing the differences in gender, age, and income}

Using the average difference test by Independent Sample T-Test and ANOVA checks whether there is a difference in the bargaining behavior of fashionable clothes in genders, age, and income. The results provide that the indifference exists between males and females while the difference exists among the different groups of age and different ranges of monthly income studied. 


\section{Table 7}

Testing the differences in age and income

ANOVA
hanhvi
\begin{tabular}{|l|r|r|r|r|r|}
\hline & Sum of & df & Mean Square & F & Sig. \\
\hline Setween Groups & 13,609 & 4 & 3,402 & 4,594 &, 001 \\
Within Groups & 159,231 & 215 &, 741 & & \\
Total & 172,840 & 219 & & & \\
\hline
\end{tabular}

ANOVA

hanhvi

\begin{tabular}{|l|r|r|r|r|} 
& $\begin{array}{c}\text { Sum of } \\
\text { Squares }\end{array}$ & df & Mean Square & F \\
\hline Between Groups & 12,488 & 4 & 3,122 & 4,186 \\
Within Groups & 160,352 & 215 &, 746 &, 003 \\
Total & 172,840 & 219 & & \\
\hline
\end{tabular}

Source: Research results

\section{Discussion and conclusion}

\subsection{Discussion}

The purpose of this study was to find out factors affecting consumer's bargaining behavior in Ho Chi Minh City when buying fashionable clothes. From the theoretical models, the previous authors showed the factors influencing consumer's bargaining behavior such as perception of price, perception of quality, subjective norm, and behavioral control. In this research, by adding interest in bargaining to the model, and it also had a strong impact on consumer's bargaining behavior. The research model became more appropriate in the context of Ho Chi Minh City and Vietnam in general.

The results of the study also showed that the perceived behavioral control was the strongest impact on consumer's bargaining behavior with $\beta$ of 0.250 . Therefore, when the level of consumer perception rises, they feel easy to make a bargain, the bargaining behavior will also increase. The next factor affecting this bargaining behavior was attitude toward bargaining $(\beta=0.240)$. It means that consumer's self-awareness about the product, the perception of price, the perception of the seller's attitude, or the perception of the place of purchase also really influenced their bargaining behavior. The last factor was interest in bargaining $(\beta=0.167)$. It is also reasonably understandable because of their interests. Moreover, bargaining behavior is the same if consumers find that bargaining is an interest, giving them a sense of fun, comfort, and they tend to do more bargaining in the future. Because of this reason, the effect of the surroundings is not significant. It can be explained by the truth that consumers bargain because they do not want to be impacted by relatives, friends, or colleagues.

Lastly, there is a difference in case that consumers who have monthly income over 15 million VNĐ are less affected by those around them than those with lower income (less than 5 million VNĐ and from 5 million VNĐ to less than 10 million VNĐ), they tend to perform behavior according to individual interests.

\subsection{Conclusion}

What makes human beings dissimilar to things and living creatures is that they can interact with each other independently without being told. Different individual has a different way to 
interact with others. Buyer and seller, as well, when they try to gain an equilibrium price for a product, they use bargaining as an interaction tool to reach both optimal party goals. In our daily life, bargaining is a practice in which a consumer and seller generate a mutually agreeable price for a product. The matter here is if the sellers and the consumers would like to limit such an action in their business and shopping or they still keep it as a better way to get more margin or more benefit compared to the real value of the product.

As presented in the research results, consumer's bargaining behavior happens due to their Attitude towards bargaining, Perceived behavioral control, and Interest in bargaining. It means that bargaining belongs firstly to consumer's attitude which is hard to change. Some of their statements are "Prices are not commensurate with the quality of goods" (mean=4.06), "Prices differ from two or more purchases for the same goods" (mean=3.74) or "I bargain because the quality of the product is not as what I expected" (mean=3.70). From that point of view, the buyers should ensure and maintain the product quality, make everything clear during the selling process, and do not exaggerate too much the selling price. Besides, the Perceived behavioral control relating to the purchase timing and buyer's characteristics also dominate the bargaining behavior, for instance, "I bargain because I realize the right time (at an empty hour, not opening time)" (mean=3.47), "I realize this seller I could bargain" (mean=3.56), or "I realize this location where I could bargain" (mean=3.77). These statements denote that the consumers on one hand love to deal with the good price as their habit, on the other hand, choose the place and the seller to bargain properly. It should be said that haggling does not come from one but two sides. For more information, in the wet markets, the seller usually tells the higher price to the buyer and the buyer thinks of bargaining immediately if he/she wants to own. That is the reason why bargaining culture endures along the time in many countries such as Vietnam, Thailand, China, ... Finally, last but not least, interest in bargaining is one of the influential factors as well. In the real-life, some people own this pleasure. More or less price discount always makes them happy and feel comfortable.

"The bargaining makes me happy because I can buy the lower price for seller's offer" (Mean=3.74) or "For me, the bargaining is as an experience, cultural discovery" (Mean=3.00).

In conclusion, for Vietnam, the country where there are 8,539 markets and nearly $75 \%$ located in rural, and thousands of street stores (Marketscreener, 2018). Bargaining is not only the usual behavior but also a specific culture that people must discover, experience, and get familiar with. Meanwhile, in the developed countries, haggling occurs very rarely because most of their markets operate under modern trade models such as department stores, shopping malls, or convenience stores where haggling is not considered useful (Putthiwanit \& Santipiriyapon, 2013). For example, Canadians think that bargaining is a useless task, so they do not want to take time to make a bargain. Perhaps that is why the seller will be proactive in setting product prices accordingly, and the buyers are flexible in finding the value of the product. According to the diversity of culture, the bargaining behavior/attitude is varied (Harack, 2011).

\section{Research limitations and future research directions}

Firstly, the research just focused on bargaining behavior when purchasing fashionable clothing in Ho Chi Minh City. Secondly, the interviewees were selected by a convenient method and the number of interviewees was still limited. Lastly, the MLR that was used to analyze the model did not evaluate the impact of each of the factors yet. For future researches, it may widen the range of studied goods/ services such as vacations, electronic devices or cosmetics, and the studied regions, e.g., Ha Noi, Da Nang. The more complicated analyzing method (SEM) must be considered to describe clearer such a typical trading behavior in Vietnam. 


\section{References}

Ajzen, I. (1991). The theory of planned behavior. Organizational Behavior and Human Decision Processes, 50(2), 179-211.

Ajzen, I., \& Fishbein, M. (1975). Belief, attitude, intention and behavior: An introduction to theory and research. Reading, MA: Addison-Wesley.

Darden, W. R., Erdem, O., \& Darden, D. K. (1983). A comparison and test of three causal models of patronage intentions. In W. R. Darden (Ed.), Patronage behavior and retail management (pp. 29-43). New York, NY: North-Holland.

Harack, B. (2011). Fact sheet on Canada post lockout: Conservatives launch blitzkrieg on unions. Retrieved August 05, 2019, from https://www.visionofearth.org/news/fact-sheet-on-canadapost-lockout-conservatives-launch-blitzkrieg-on-unions/

Kotler, P. (1973). Atmospherics as a marketing tool. Journal of Retailing, 49(4), 48-64.

Kwon, K. N., Schumann, D. W., \& Fairhurst, A. (2010). Consideration of an expected future deal in assessing the value of a present deal: Forward-looking bargain shopping. Journal of Business Research, 63(1), 84-90. doi:10.1016/j.jbusres.2009.02.015

Lee, D. Y. (2000). Retail bargaining behaviour of American and Chinese customers. European Journal of Marketing, 34(1/2), 190-206. doi:10.1108/03090560010306287

Lichtenstein, D. R., Ridgway, N. M., \& Netemeyer, R. G. (1993). Price perceptions and consumer shopping behavior: A field study. Journal of Marketing Research, 30(2), 234-245. doi: $10.2307 / 3172830$

Marketscreener. (2018). Nielsen: Reports 4th quarter and full year 2017 results. New York, NY: Marketscreener.

Nguyen, H. T. T. (2018). Điểm khác biệt trong hành vi mua hàng của nam và nữ [Differences in purchasing behavior for men and women]. DTC - Control in Your Hand. Retrieved August 06, 2019, from https://dtctech.vn/tin-nong/hanh-vi-mua-hang-cua-nam-va-nu

Nguyen, T. D. (2011). Phương pháp nghiên cúu khoa học trong kinh doanh [Methods of scientific research in business]. Ho Chi Minh City, Vietnam: Lao Dong - Xa hoi.

Novemsky, N., \& Schweitzer, M. E. (2004). What makes negotiators happy? The differential effects of internal and external social comparisons on negotiator satisfaction. Organizational Behavior and Human Decision Processes, 95(2), 186-197. doi:10.1016/j.obhdp.2004.05.005

Osman-Gani, A. M., \& Tan, J. S. (2002). Influence of culture on negotiation styles of Asian managers: An empirical study of major cultural/ethnic groups in Singapore. Thunderbird International Business Review, 44(6), 819-839. doi:10.1002/tie.10048

Putthiwanit, C. (2016). An analysis of Joseph Schumpeter's life, concept of innovation, and application for Estonia. Paper presented at British Association for Slavonic and East European Studies 2016 Annual Conference (BASEES 2016), At Fitzwilliam Colleges, University of Cambridge. doi:10.13140/RG.2.1.3939.5440

Putthiwanit, C., \& Santipiriyapon, S. (2013). Apparel bargaining behavior, action, intention to rebargain, and repurchase intention between Thai and Chinese consumers. Paper presented at Preparation and Impact of Workforce Movement due to AEC Framework, at Eastern Asia Univeristy. doi:10.13140/RG.2.1.3753.7363

Von Freymann, J. (2002). Grocery store pricing and its effect on initial and ongoing store choice. Marketing Management Journal, 12(1), 107-119. 